RADOSŁAW FIEDLER

Uniwersytet im. Adama Mickiewicza w Poznaniu

DOI : $10.14746 /$ rie.2016.10.23

\title{
Unia Europejska na rzecz demokratyzacji państw Azji Centralnej - działania i efekty ${ }^{1}$
}

Rozpad Związku Radzieckiego oznaczał dla państw regionu Azji Centralnej uzyskanie niezależności od Moskwy. Sam region zyskał podmiotowość geopolityczną i niemal od razu stał się przedmiotem rywalizacji pomiędzy Federacją Rosyjska, ChRL, Stanami Zjednoczonymi, Turcją, a także Iranem. Największe wpływy polityczne w Azji Centralnej zachowała Federacja Rosyjska. Nadal dla Moskwy region ten określany jest jako bliska zagranica. Dla Chin region ten jest ważny pod względem energetycznym jak i geostrategicznym - nowy jedwabny szlak.

Natomiast dla Stanów Zjednoczonych państwa Azji Centralnej poprzez swoje położenie stały się zapleczem dla misji Międzynarodowej Siły Wsparcia Bezpieczeństwa (ang. International Security Assistance Force - ISAF) w Afganistanie. Zarówno władze Uzbekistanu, jak i Kirgistanu bez początkowego sprzeciwu Moskwy, wyraziły zgodę na utworzenie na ich terytorium amerykańskich baz wojskowych. Zgoda okazała się czasowa, a w przypadku Uzbekistanu zakończona przed terminem. Obawy Rosji i Chin, że amerykańskie zaangażowanie w Azji Centralnej po 2001 r. doprowadzi do większej obecności USA w tym regionie okazało się przedwczesne. W polityce Waszyngtonu, kwestia praw człowieka nie była pomijana pomimo strategicznej współpracy z Uzbekistanem. W 2005 r. USA potępiły krwawą pacyfikację demonstracji w Andiżanie w maju 2005 roku. Doszło do ochłodzenia stosunków na linii TaszkientWaszyngton, a amerykańska baza wojskowa w Uzbekistanie została zamknięta przed terminem (Azhiben, 2008, s. 1-11).

$\mathrm{Na}$ tle innych aktorów zewnętrznych polityka Unii Europejskiej wobec Azji Centralnej oraz jej działania są nader skromne jak na możliwości i potencjał UE. $\mathrm{Na}$ początku lat 90-tch, region Azji Centralnej był jedynie ujmowany jako jeden z elementów składowych Wspólnoty Niepodległych Państw. Wspólnoty Europejskie przede wszystkim planowały układać sobie relacje z Rosją i Ukrainą w pierwszym rzędzie, dopiero potem $\mathrm{z}$ innymi państwami, które wyłoniły się w wyniku rozpadu ZSRR. Dynamika zmian oraz doniosłe konsekwencje związane z nowymi uwarunkowaniami geopolitycznymi oraz geostrategicznymi, zdawały się nie być dostrzegane w tamtym czasie przez Brukselę. Największym wyzwaniem w tamtym okresie był konflikt w b. Jugosławii i jego możliwe negatywne konsekwencje dla bezpieczeństwa europejskiego, aniżeli rozwój wydarzeń w odległych republikach środkowoazjatyckich.

${ }^{1}$ Artykuł został przygotowany w ramach projektu finansowanego przez Narodowe Centrum Nauki: „Unia Europejska wobec Azji Środkowej - uwarunkowania regionalne i międzynarodowe” 2014/15/B/HS5/01591. 
W tamtym okresie jedynie Republika Federalna Niemiec posiadała swoje przedstawicielstwa dyplomatyczne we wszystkich pięciu środkowoazjatyckich republikach, a Francja i Wielka Brytania w większości z nich. Pozostałe państwa członkowskie Wspólnot Europejskich jeśli były zainteresowane regionem, jeśli już podejmowały jakieś działania, to czyniły to za pośrednictwem Ankary oraz Moskwy.

Przykładanie niewielkiego znaczenia dla Azji Centralnej przez decydentów państw członkowskich oraz urzędników w instytucjach i departamentach UE skutkowało tym, że nie było przez wiele lat żadnej strategii wobec tego regionu, w której określone zostałby priorytety europejskiego w nim zaangażowania. Brak rozległych kontaktów i orientacji oraz nieumiejętność wykorzystania własnego potencjału, a także zazwyczaj opóźniona reakcja na przemiany w Azji Centralnej niejednokrotnie potwierdzały, że UE nie miała ambicji do odgrywania samodzielnej roli politycznej. Nawet Iran i Turcja były znacznie bardziej aktywne, aniżeli UE.

Pierwsze kroki związane z instytucjonalizacją współpracy UE z państwami Azji Centralnej było otwarcie w 1999 r. Delegatury Komisji Europejskiej w Kazachstanie. Za jej pośrednictwem koordynowano programy i inicjatywy adresowane także wobec pozostałych państw regionu. Formalnym krokiem w inicjowaniu działań UE wobec państw WNP było zawarcie Umów o Partnerstwie i Współpracy (Patrnersip and Cooperation Agreements - PCA). Należy wspomnieć, że umowa taka została zawarta między UE a państwami regionu Azji Centralnej dopiero w klika lat później po zawarciu analogicznych umów z Rosją i Ukrainą. Umowa o Partnerstwie i Współpracy przewidywała dość szeroką płaszczyznę współpracy pomiędzy UE a partnerami z WNP. W jej ramach deklarowano wypracowanie odpowiednich ram dla rozwijania politycznego dialogu, wspieranie starań na rzecz demokratyzacji oraz działań ukierunkowanych na rozwój gospodarki rynkowej, promowanie handlu i inwestycji, określenie ram dla prawnej, gospodarczej, społecznej, finansowej, naukowej, technologicznej oraz kulturalnej współpracy (PCA Kazakhstan, 1996).

W ramach partnerstwa widoczne były różne priorytety, jakie stawiała przed sobą UE wobec poszczególnych państw WNP. Przykładowo w ramach umów o partnerstwie z Rosją, Ukrainą oraz Mołdową znalazła się deklaracja, że przyszłym celem miło być utworzenie strefy wolnego handlu pomiędzy tymi państwami a UE. Nie było takiej deklaracji $\mathrm{w}$ analogicznych umowach $\mathrm{z}$ państwami środkowoazjatyckimi. Jednak najbardziej widocznym przejawem nieprzywiązywania strategicznej roli regionowi Azji Centralnej był rozdział środków w ramach programu pomocy technicznej TACIS adresowanego do państwa WNP (Technical Assistance for the Commonwealth of Independent States). O ile dla Rosji zarezerwowano fundusze w ramach TACIS w wysokości 1,27 mld euro, dla Ukrainy 460,8 mln euro, o tyle dla pięciu państw środkowoazjatyckich kwota ta wynosiła jedynie 311,8 mln euro (Delcour, 2011, s. 94).

W podejściu UE wobec państw Azji Centralnej ważną cezurą jest rok 2001. Region ten uznany został przez Waszyngton za kluczowy do prowadzenia militarnych działań w Afganistanie. Zmiana nastawienia USA miała wpływ na nadanie nowej dynamiki dla działań UE adresowanych do regionu Azji Środkowej. Dla państw środkowoazjatyckich oznaczało to możliwość lawirowania pomiędzy USA, Rosją a Chinami i zabieganie o jak najlepsze warunki współpracy. Dla Waszyngtonu re- 
gion ten postrzegany był przede wszystkim jako logistyczne zaplecze dla operacji ISAF w Afganistanie.

Inicjatywy UE odzwierciedlały także priorytety USA wobec regionu Azji Centralnej, a jednym z nich był istoty problem uszczelnienia granic pomiędzy republikami środkowoazjatyckimi by zapobiec przemytowi narkotyków. W tym celu rozwinięto istniejący od 1996 r. Central Asia Drug Assistance Programme (CADAP), a po 2001 r. dodatkowo wprowadzono program Border Management Programme in Central Asia (BOMCA) (Matveeva, 2006, s. 96).

Zasadniczym przełomem było ogłoszenie w czerwcu 2007 r. przez Radę Europejską Strategii na Nowe Partnerstwo (ang. Strategy for a New Partnership) dla regionu Azji Centralnej (The European Union and Central Asia: The New Partnership in action, 2009). W dokumencie tym przewidziano także działania na rzecz wspierania procesów demokratyzacyjnych oraz rozwoju społeczeństwa obywatelskiego. Do tej pory te kwestie nie były wyeksponowane w relacjach unijno-środkowoazjatyckich jako jeden z długofalowych priorytetów. Przykładowo w latach 2002-2006, Bruksela w relacjach z państwami regionu skoncentrowana była przede wszystkim na promowaniu handlu i inwestycji w przemysł gazowy oraz rozwijanie transportu (Crawford, 2008, s. 170-180). Takim działaniem była harmonizacja standardów związanych z wymogami stawianymi węglowodorom z Azji Centralnej, aby odpowiadały normom unijnym. UE finansowała w tamtym okresie różne infrastrukturalne projekty, przede wszystkim związane z sektorem energetycznym, na który przeznaczono $45 \mathrm{mln}$ euro, a z kolei na transport $29 \mathrm{mln}$ euro. Celem inwestycji w ramach funduszy unijnych było także zainteresowanie europejskich koncernów energetycznych większą aktywnością w tym regionie. W latach 2002-2006 innym obszarem działań UE był program Wolność, Bezpieczeństwo i Sprawiedliwość w ramach trzech obszarów: zwalczania zorganizowanej przestępczości, zarządzanie granicami oraz polityką azylową. Na te cele przeznaczono łącznie w tamtym okresie $112 \mathrm{mln}$ euro. Ponadto w latach 2002-2006 był jeszcze unijny instrument finansowy w ramach programów realizowanych we współpracy dwustronnej. Z kwoty 142 mln euro około 60\% środków przeznaczonych zostało na przeciwdziałanie ubóstwu i wykluczeniu, z kolei $20 \%$ na wspieranie reform administracyjnych. Wreszcie pozostałe $20 \%$ miało zostać przeznaczone na wsparcie instytucji społeczeństwa obywatelskiego. Niestety gros z tych środków trafiło do organizacji powiązanych z administracją publiczną (Crawford, 2008, s. 180).

Strategia z 2007 r. większy nacisk kładła na prawa człowieka i wspieranie demokratyzacji, aniżeli poprzednie unijne działania. Zainicjowanie strategii szło w parze ze zmianami strukturalnymi w działaniach UE. Dotychczasowa Europejska Inicjatywa na rzecz Demokracji oraz Praw Człowieka (European Initiative on Democracy and Human Rights) (1994-2006), zastappiona została przez Europejski Instrument na Rzecz Demokracji i Prawa Człowieka (ang. European Instrument for Democracy and Human Rights - EIDHR) z budżetem rocznym wynoszącym $140 \mathrm{mln}$ euro. Nowy instrument miał być zdecydowanie bardziej ukierunkowany na finansowanie i pomoc niezależnym organizacjom społeczeństwa obywatelskiego także w państwach środkowoazjatyckich (Axyonova, 2012).

Ponadto w strategii UE ujęto region Azji Centralnej jako całość i podkreślono w niej wspieranie dotychczasowych działań ukierunkowanych na rozwój współpracy 
z poszczególnymi państwami. Jak podkreślono w tym dokumencie, w celu promowania pokoju, demokracji i dobrobytu gospodarczego w Azji Centralnej zaproponowano następujące działania i inicjatywy:

1) skuteczne wykorzystanie instrumentów, programów, umów o współpracy i dialogu politycznym;

2) zaproponowano zrównoważenie podejść dwustronnych za pomocą działań mających na celu sprostanie wspólnym wyzwaniom regionalnym;

3) zidentyfikowano siedem głównych obszarów politycznych o szczególnym znaczeniu: a) dobre rządy, praworządność, prawa człowieka oraz demokratyzacja; b) kształcenie i szkolenie; c) rozwój gospodarczy, handel i inwestycje; d) transport i energia; e) zrównoważenie środowiskowe i gospodarka wodna; f) radzenie sobie ze wspólnymi zagrożeniami i wyzwaniami; g) dialog międzykulturowy;

4) zwiększono budżet pomocowy UE w perspektywie finansowej 2007-2013 do $750 \mathrm{mln}$ euro (Europejski Trybunał Obrachunkowy, 2013, s. 10).

Przyjęcie strategii dowodziło, że państwom Azji Centralnej zaproponowano różne działania oraz programy i z czasem mogły się one przyczynić do większego zaangażowania UE na tym obszarze. Pod koniec 2009 r. Komisja Europejska przekształciła swoje oddziały w Kirgistanie i Tadżykistanie w pełnoprawne delegatury UE. W 2012 r. utworzono delegaturę UE w Uzbekistanie. Jeszcze dwa lata przed ogłoszeniem strategii Rada Europejska mianowała Specjalnego Przedstawiciela Unii Europejskiej w Azji Centralnej. Do jego głównych zadań należało wspieranie dobrych stosunków między UE a państwami Azji Centralnej oraz wzmacnianie stabilności, współpracy, demokracji i poszanowania praw człowieka w regionie, reagowanie na kluczowe zagrożenia, w szczególności konkretne problemy mające bezpośrednie skutki dla Unii jak również zwiększanie skuteczności i widoczności UE w regionie (Decyzja Rady 2016/596). Problem polega na tym, że urząd ten znajduje się w Brukseli, a nie np. w Astanie.

W latach 1991-2013 UE przeznaczyła na pomoc rozwojową i humanitarną dla państw środkowoazjatyckich ponad 2,1 mld euro, z czego $750 \mathrm{mln}$ euro w okresie 2007-2013. Początkowo fundusze były przekazywane za pomocą programu TACIS, a począwszy od 2007 r. w ramach Instrumentu Współpracy na Rzecz Rozwoju (Development Cooperation Instrument - DCI). Finansowanie odbywało się także w ramach innych działań, takich jak EIDHR czy Instrumentu na Rzecz Stabilności (Instrument for Stability - IfS) razem z mechanizmem szybkiego reagowania.

Mimo znacznego po 2001 r. zwiększenia unijnych funduszy wobec regionu Azji Centralnej, stanowiły one niewielką część ogólnych przepływów finansowych kierowanych do regionu. Szczególnie w przypadku Kazachstanu, Turkmenistanu i Uzbekistanu oficjalna pomoc rozwojowa $z$ lat 2007-2013 stanowiła mniej niż 5\% rocznych bezpośrednich inwestycji zagranicznych (i mniej niż $0,2 \%$ rocznego produktu krajowego brutto (Europejski Trybunał Obrachunkowy, 2013, s. 12).

Jednym z widoczniejszych działań UE w ramach strategii z lat 2006-2013 było wspieranie rozwoju szkolnictwa wyższego w ramach następujących programów Tempus, Erasmus Mundus Partnerships (Action 2) oraz Central Asia Research and Education Network (CAREN). Największy budżet w latach 2007-2012 miał program Erasmus Mundus, na realizację którego przeznaczono $€ 195$ milionów. Sfinansowano 
stypendia i wymianę dla ponad 9,5 tysiąca studentów i kadry naukowej z regionu Azji Środkowej. Stypendia finansowane przez UE wahały się od jednego miesiąca w przypadku kadry naukowej do 14, a nawet 18 miesięcy dla studentów studiów magisterskich i doktoranckich (Central Asia - Education and research).

Najpoważniejszą przeszkodą dla działań UE na rzecz wspierania procesów demokratyzacji stanowi autorytarny charakter systemu władzy w republikach ,prezydenckich”. Autorytarni przywódcy nie są zainteresowani głębszą liberalizacją polityczną, rządami prawa czy budową instytucji społeczeństwa obywatelskiego, które mogłyby ograniczyć ich władzę. Specyfika systemów politycznych państw Azji Centralnej polega na utrwalaniu modelu autorytarnego, a nawet występowania elementów systemu totalitarnego w Turkmenistanie. Państwa tego regionu po 1991 r. były budowane w skomplikowanych uwarunkowaniach politycznych, narodowościowych czy religijnych. Istotnym elementem umacniania podmiotowości państwowej i międzynarodowej było rozwijanie silnego przywództwa w państwach regionu (Bodio, Załęski, 2008, s. 260). System politycznoprawny ma charakter hybrydalny i pomimo różnic pod względem dostępu do zasobów naturalnych oraz poziomu swobód obywatelskich, państwa tego regionu mają wiele cech wspólnych. Na kształtowanie się systemu politycznego i prawnego wpływ miały doświadczenia radzieckie, zaadaptowane elementy demokracji zachodnich, tendencje autorytarne, lokalne uwarunkowania kulturowe oraz specyficzna struktura społeczna w poszczególnych państwach tego regionu. Konstytucje oraz system prawny służył autolegitymizacji prezydentów republik środkowoazjatyckich. Prezydencki ośrodek władzy decyduje w tym systemie o wielu politykach, inicjatywach, działaniach czy różnych programach. Silnie spersonalizowana władza wykonawcza, brak wystarczającej ochrony prawnej, korupcja oraz uzależnienie wielu kwestii od politycznej woli prezydenta utrudniają w istotny sposób przeprowadzenie modernizacji oraz napływ długotrwałych inwestycji. Taka sytuacja powoduje, że gospodarka oparta jest na sprzedaży surowców, które przynoszą stosunkowo szybkie dochody lokalnym elitom, jak i koncernom międzynarodowym (Shukuralieva, 2013). Autorytarny model władzy w republikach środkowoazjatyckich ma swoją regionalną specyfikę. Być może zapoczątkowanie głębszych przemian w którymś z państw regionu może zapoczątkować efekt domina w pozostałych. Wydawać się mogło, że Kirgistan, w którym udało się doprowadzić do odsunięcia autokraty, aspiruje do miana awangardy przemian politycznych w regionie. Dwukrotnie prezydenci tego państwa byli odsuwani w rezultacie kryzysów politycznych. Szczególnie po 2005 r. Pierwszy z nich, który ustapił to Askar Akaev (1990-2005), drugi z kolei Kurmanbek Bakiev był prezydentem jeszcze krócej - jego rządy przypadały na lata 2005-2010 (McGlinchey, Project, 2011, s. 80-88). Kryzysy polityczne nie zmieniły jednak zakorzenionego modelu politycznego, w którym silne tendencje autorytarne dodatkowo wzmocnione są przez problem powszechnej korupcji. Jest ona jednym z poważniejszych wyzwań hamujących rozwój i procesy modernizacyjne. Na podstawie badań przeprowadzonych w tym względzie przez Transparency International z $2015 \mathrm{r}$. Kirgistan znalazł się na 123, Tadżykistan na 136, Uzbekistan na 153 a Turkmenistan najgorzej bo 154 miejscu na 168 państw uwzględnionych w rankingu. Korupcja jest problemem całego regionu (Transparency International, 2016).

Innym czynnikiem zewnętrznym w znacznej mierze utrudniającym przemiany demokratyczne w regionie jest autorytarne sąsiedztwo. Jak zauważył przed laty Ah- 
med Rashid, region Azji Centralnej stał się przedmiotem nowej wielkiej gry (Rashid, 1997). Na taką sytuację wpływ ma strategiczne położenia: granice z Rosją, zachodnimi Chinami, Afganistanem i Iranem, Morzem Kaspijskim oraz bogate złoża zasobów energetycznych. Nie tylko najbliższe pogranicze, ale także potrzeby energetyczne kierują uwagę Chin w stronę tego regionu. Największe złoża surowcowe oraz największą gospodarkę posiada Kazachstan. Turkmenistan jest natomiast zasobny w gaz ziemny. $\mathrm{Z}$ pominięciem tranzytu przez Rosję ropa z Kazachstanu jest eksportowana do Chin, a od 2009 r. gaz z Turkmenistanu (Gacek, 2013, s. 47-62).

Handlowo-gospodarczą inicjatywą Rosji jest osiągnięcie w 2015 r. Euroazjatyckiej Unii Gospodarczej. Unia ma przede wszystkim charakter polityczny, wskazują na to dane. Produkt krajowy brutto Rosji stanowi ok. 86\% PKB całego EUG. PKB drugiego pod względem wielkości i potencjału gospodarczego Kazachstanu stanowi niecałe $10 \%$, około 3,5\% przypada na Białoruś, a niespełna 1\% na Armenię i Kirgistan. Relacje handlowe w ramach EUG są silnie zdominowane przez handel poszczególnych krajów z Rosją (z przewagą eksportu z Rosji). Dominujący w ramach EUG dwustronny, aniżeli wielostronny układ wymiany handlowej pomiędzy poszczególnymi państwami a Rosją powoduje cały szereg napięć i może w poważnym stopniu uzależnić uczestników EUG od kondycji gospodarki rosyjskiej (Wiśniewska, 2013, s. 37-40). Problemy gospodarcze i kryzys finansowy w Rosji ma wpływ na koniunkturę w Kazachstanie i Uzbekistanie.

Konflikt na wschodzie Ukrainy po 2014 r. i anektowanie Krymu przez Federację Rosyjską dowodzi, iż kwestia mniejszości rosyjskiej w poszczególnych państwach Azji Centralnej może zostać wykorzystana jako instrument w polityce rosyjskiej wobec państw tego regionu. Rosjanie stanowią około $22 \%$ populacji Kazachstanu, z czego ledwie $0,9 \%$ zna język kazachski, w Kirgistanie etniczni Rosjanie stanowią $7 \%$ populacji, w Uzbekistanie 3\%, Turkmenistanie 2\%, a w Tadżykistanie około 1\%. Innym instrumentem potencjalnego oddziaływania Rosji na poszczególne państwa regionu są migranci zarobkowi głównie pochodzący z Kirgistanu oraz Tadżykistanu, którzy znaleźli zatrudnienie na terytorium Rosji. Jakiekolwiek restrykcje i ograniczenia czy kryzys na rosyjskim rynku pracy mogą negatywnie zaważyć na płynności finansowej tych państw („Rocznik Strategiczny”, 2015, s. 381).

Mając na uwadze zarówno korzyści, jak i wyzwania wynikające z autorytarnego sąsiedztwa, jakakolwiek głębsza zmiana polityczna i próba przeorientowania priorytetów polityki zagranicznej może doprowadzić nawet do bezpośredniej interwencji, jeśli wspomniane instrumenty mogłyby zawieść.

Państwa Azji Centralnej przede wszystkim orientują się na współpracę ze swoimi sąsiadami. Jeśli UE nie sformułuje kolejnej strategii, a co za tym idzie, nie zaoferuje odpowiednich programów, inicjatyw i działan, to przestanie być liczącym się partnerem, który mógłby aspirować do poważniejszej roli.

\section{Wnioski}

Państwa regionu Azji Centralnej borykają się z wieloma problemami takimi jak: silne tendencje autorytarne, zacofanie gospodarcze, zbytnie uzależnienie od docho- 
dów z eksportu ropy i gazu, konflikty etniczne, klanowe, problem zasobów wodnych, przemyt narkotyków, powszechna korupcja i ekstremizm islamski. Dotychczasowa współpraca UE z państwami Azji Centralnej nie wpłynęła na poprawienie negatywnych tendencji oraz autorytarnego systemu politycznego.

Analizując przyczyny niewielkiego wpływu UE na demokratyzację państw środkowoazjatyckich, należy zwrócić uwagę na następujące kwestie:

1. Azja Centralna przez długi czas nie była traktowana jako region, który miałby istotne znaczenie geostrategiczne dla UE.

2. Większe zaangażowanie się UE pojawiło się dopiero wskutek zainteresowania USA Azją Centralną głównie ze względu na misję ISAF w Afganistanie oraz problem przemytu narkotyków na dużą skalę.

3. Zaproponowana w latach 2007-2013 przez UE strategia wobec Azji Centralnej była jak do tej pory najważniejszą unijną inicjatywą wobec tego regionu.

4. Przeważająca część środków w ramach funduszy była przeznaczana na pomoc rozwojową, ale także nie zabrakło środków na zwiększenie mobilności studentów i badaczy do uniwersytetów w UE. Stawiając na kształcenie przyszłych elit liczono, że z czasem zapoczątkują proces liberalizacji i modernizacji.

5. Jednym $z$ widocznych problemów UE jest pewnego rodzaju chaos kompetencyjny związany z nakładaniem się działań różnych unijnych inicjatyw wobec regionu Azji Centralnej.

6. Po 2014 r. USA stopniowo zmniejsza swoją aktywność strategiczną w Azji Centralnej, także UE nie sformułowała nowej strategii wobec tego regionu, dowodzi to jedynie niechęci UE do odegrania bardziej samodzielnej roli w polityce wobec tego regionu.

7. UE przedkładała swoje interesy energetyczne nad kwestie związane z ochroną praw człowieka czy wspieraniem procesów demokratyzacyjnych. Nie Stały się one poważnym programem działania, który dodatkowo wzmocniony wiązałby warunkowo udzielaną pomocą finansową z określonymi reformami politycznymi.

8. Nadal bardzo poważnym hamulcem rozwojowym dla państw Azji Centralnej są silne tendencje autorytarne, które są także uwarunkowane historycznie oraz problem niemal powszechnej korupcji.

9. Biorąc pod uwagę uwarunkowania wewnętrzne państwa Azji Centralnej znajdują się pomiędzy autorytaryzmem: Kazachstan, Kirgistan, Tadżykistan a państwami mającymi pewne cechy odpowiadające systemom totalitarnym jak Uzbekistan czy Turkmenistan.

10. Najważniejszymi aktorami zewnętrznymi silnie oddziałującymi na region Azji Centralnej są Rosja i Chiny. Ich polityka ma wpływ na wspieranie od zewnątrz tendencji autorytarnych $\mathrm{w}$ tym regionie.

\section{Bibliografia}

Axyonova V. (2012), EU Human Rights and Democratisation Assistance to Central Asia: In Need of Further Reform (10.09.2016).

Bodio T., Załęski P. (2008), Problemy budowy społeczeństwa obywatelskiego w państwach Azji Centralnej, w: Region Azji Centralnej jako obszar wpływów międzynarodowych, pod red. B. Bojarczyka, A. Ziętek, Lublin. 
Central Asia - Education and research, http://ec.europa.eu/europeaid/regions/central-asia/eu-support-education-and-research-cooperation-central-asia_en.

Crawford G. (2008), EU human rights and democracy promotion in Central Asia: From Lofty principles to Lowly self-interests, „Perspectives On European Politics \& Society”, 9, 2, s. $172-191$.

Central Asia Population (2016), http://www.worldometers.info/world-population/central-asiapopulation/, 17.05.2016.

Cierpiński Z. (2009), Kotlina Fergańska rozsadnik „,narkoislamizmu, http://www.psz.pl/116bezpieczenstwo/kotlina-ferganska-rozsadnik-narkoislamizmu, 13.05.2016.

Delcour L. (2011), Shaping the Post-Soviet Space? EU Policies and Approaches to Region-Building, Burlington.

The European Union and Central Asia: The New Partnership in action (2009), http://eeas.europa.eu/ central_asia/docs/2010_strategy_eu_centralasia_en.pdf, 10.06.2016.

Hartman J. W. (2016), The May 2005 Andijan Uprising: What We Know, Central Asia-Caucasus Institute \& Silk Road Studies Program-A Joint Transatlantic Research and Policy Center, „Silk Road Paper”.

Gacek Ł. (2013), Azja Centralna w polityce energetycznej Chin, Wydawnictwo Uniwersytetu Jagiellońskiego, Kraków.

Kozłowski K. (2012), Kolory Rewolucji, Poltext, Warszawa.

Lang J. (2013), The radical Islamic militants of Central Asia, New York.

Matveeva A. (2006), EU Stakes in Central Asia, "Chaillot Papers", no. 91, July, special issue.

McGlinchey E. Project M. (2011), Chaos, Violence, Dynasty : Politics And Islam In Central Asia, University of Pittsburgh Press, Pittsburgh.

Micklin P. (2007), The Aral Sea Disaster, „Annual Review of Earth and Planetary Sciences”, vol. 35, http://www.terras-altas.net.br/MA-2013/desastres\%20ambientais/AralSeaDisaster.pdf, 18.05.2016.

Olcott M. B. (2012), In The Whirlwind Of Jihad, Brookings Institution Press, Washington, DC.

PCA-Kazakstan (1996), http://ec.europa.eu/external_relations/central_asia/pca/index_en.htm, 10.06.2016.

Perkowska A. (2013), Dezintegracja regionu Azji Centralnej jako pochodna uwarunkowań wewnętrznych, „Polityka i Bezpieczeństwo”, nr 2.

Pomoc Rozwojowa dla UE dla Azji Środkowej (2013), Europejski Trybunał Obrachunkowy. Sprawozdanie Specjalne nr 13.

Rashid A. (1997), The New Great Game - the Battle for Central Asia's Oil, „Far Eastern Economic Review", 10 April.

Rashid A. (2003), Dżihad. Narodziny wojującego islamu w Azji Środkowej, Warszawa.

„Rocznik Strategiczny” 2014/15 (2015), Przeglad sytuacji politycznej, gospodarczej $i$ wojskowej w środowisku międzynarodowym Polski, t. 20, Warszawa.

Shukuralieva N. (2013), Globalny rozwój w kontekście społeczno-gospodarczych wyzwań Azji Środkowej i Kaukazu Poludniowego, projekt wspólfinansowany przez Ministerstwo Spraw Zagranicznych RP w ramach programu Polska Pomoc.

Sikorski T. (2010), Masakry etniczne w Kirgistanie przyczyny oraz reakcje międzynarodowe, „Biuletyn” Polskiego Instytutu Stosunków Międzynarodowych, nr 98, Warszawa, http://www. pism.pl/zalaczniki/Biuletyn_706.pdf, 15.05.2016.

Słojewska A., Wielkie bitwy o wodę, http://www.rp.pl/artykul/1035598-Wielkie-bitwy-o-wode.htm1\#ap-2, 17.05.2016.

Stein M. (2012), Uzbekistan's View of Security in Afghanistan After 2014, „Military Review”, vol. 92 , issue 3. 
Transparency International (2015); http://www.transparency.org/country\#TKM.

Wiśniewska I. (2013), Integracja euroazjatycka rosyjska próba ekonomicznego scalenia obszaru poradzieckiego, „Prace OSW”, nr 44, Warszawa.

World Drug Report (2013), United Nations on Drugs and Crime, Vienna.

\section{Streszczenie}

Unia Europejska dopiero w 2007 r. zaproponowała wobec regionu Azji Centralnej strategię, w której odniesiono się do różnych problemów, w tym deficytu demokracji i łamania praw człowieka. Istotnym ograniczeniem działań UE jest występowanie w cieniu USA oraz brak ambicji by także rozwijać współpracę w innych obszarach jak bezpieczeństwo czy zwiększenie europejskich inwestycji. Kolejnym problemem jest po zakończeniu jedynej strategii brak nakreślenia priorytetów, które umożliwiłoby UE na odgrywanie większej roli w Azji Centralnej.

Słowa kluczowe: Unia Europejska, Azja Centralna, autorytaryzm, liberalizacja

\section{The European Union for the democratization of states in Central Asia - activities and results}

\section{Summary}

European Union after years of relatively small activity, in 2007 offered a strategy to Central Asia. In that strategy were addressed many issues, including democratic deficit or human rights violations. EU in its activity is overshadowed by the US and has small capacity for pursuing its own policy to the Central Asia. Another problem is a fact that after accomplishing EU strategy to Central Asia there are no new initiatives which will contribute for more visible European activity in that region.

Key words: European Union, Central Asia, authoritarianism, liberalization 
